Acta vet. scand. 1986, 27, 303-312

From the Department of Obstetrics and Gynaecology, Swedish

University of Agricultural Sciences, Uppsala, Sweden.

\title{
SPERM LOCALIZATION IN THE OVIDUCTS OF ARTIFICIALLY INSEMINATED DAIRY CATTLE
}

By

B. Larsson and $K$. Larsson

LARSSON, B. and K. LARSSON: Sperm localization in the oviducts of artificially inseminated dairy cattle. Acta vet. scand. 1986, 27, 303-312. - Eight animals, 3 heifers and 5 primiparous cows, were artificially inseminated by intrauterine deposition of frozen-thawed semen. The insemination dose comprised $20 \times 10^{6}$ or $200 \times 10^{6}$ spermatozoa, frozen in French mini straws. Four animals were inseminated at fixed time interval $(72$ or $84 \mathrm{~h}$ ) after cloprostenol injection. The remaining 4 animals were inseminated in spontaneous oestrus. Slaughter took place 2 or $12 \mathrm{~h}$ after insemination. After fixation the oviducts were cut into segments, which were serial-sectioned and stained. Six sections per segment were examined under the microscope for sperm recovery.

The number of spermatozoa recovered from the oviducts varied considerably among animals. Recovery was poor (less than 50 spermatozoa) in 4 animals. Recovery was low when insemination took place in induced oestrus and with the lower sperm number $\left(20 \times 10^{6}\right)$. In animals in which more than 50 spermatozoa were found the distribution varied both between animals and between oviducts within the same animal. Overall, more spermatozoa were found in the lower (UTJ, isthmus and AIJ) than in the upper (ampulla) parts of the oviducts. In 3 out of 4 animals more spermatozoa were recovered from the left than from the right oviduct. Only in 1 animal were the majority of spermatozoa found in the oviduct ipsilateral to the follicle-bearing ovary.

sperm distribution; bovine uterine tube; frozen semen; serial section.

Despite the world-wide use of frozen semen in artificial insemination (AI) of cattle only a few studies have been performed to investigate the sperm distribution and localization in the female genital tract after AI with frozen semen. In most of the studies on sperm distribution in the bovine, sperm recovery has been obtained by flushing of the female genital tract (Dobrowolski \& Hafez 1970, El-Banna \& Hafez 1970, Larsson \& Larsson 
1985). These studies have mainly been aimed at clarifying sperm numbers in different parts of the female tract at various times after AI or natural mating.

To get more precise information concerning sperm localization within the various segments of the female tract serial sectioning and microscopic evaluation of such segments may be undertaken. In one study using such a technique Thibault et al. (1973) found that sperm distribution within the isthmus and ampulla of cattle varied between $2 \mathrm{~cm}$ segments of the organ.

When AI with frozen semen is used, its timing relative to the time of ovulation as well as sperm numbers in the inseminate are believed to be of importance for fertility. Hence these factors need to be studied also in relation to sperm transport and distribution. One way to facilitate studies of sperm distribution in relation to the time of ovulation would be to inject females with prostaglandins during the luteal phase of the oestrous cycle and thereafter inseminate at a fixed time after prostaglandin injection.

In the aforementioned studies, using flushing of the female tract for sperm recovery, only a minor portion of the spermatozoa were recovered from the uterine horns and oviducts. It is therefore important to investigate whether sperm recovery will be high enough to allow studies on distribution if $20 \times 10^{6}$ spermatozoa, i.e. the number of spermatozoa routinely used for $A I$ in Sweden, are used.

The aims of this study were to:

- investigate the localization of spermatozoa within the oviducts of artificially inseminated cattle 2 and $12 \mathrm{~h}$ after AI,

- evaluate whether studies on sperm distribution, after AI, can be performed when standard sperm numbers are inseminated,

- evaluate the possibility to use fixed time AI after prostaglandin injections in sperm distribution studies.

Parts of the results were previously presented in a short paper (Larsson 1984).

\section{MATERIALS AND METHODS}

\section{Animals}

Eight animals (A-F), 6 of the Swedish Red and White breed and 2 of the Swedish Friesian breed, were used in this study. Five of them were dry primiparous cows culled due to low millk 
production and 3 were heifers aged $19-25$ months (Table 1). All animals were observed during at least 1 oestrous cycle before they were used in the experiment. They were checked for external signs of oestrus $2-3$ times a day.

\section{Insemination and semen}

The semen used in this experiment derived from 1 ejaculate from a bull with proven good fertility. The semen was frozen in French mini straws as described by Larsson \& Larsson (1985). The straws contained $20 \times 10^{6}$ or $200 \times 10^{6}$ spermatozoa. Immediately before insemination the semen was thawed in water $\left(35^{\circ} \mathrm{C}, 12 \mathrm{~s}\right)$. The time for insemination is shown in Table 1 .

Table 1. Experimental animals, regime of insemination and slaughter and number of recovered spermatozoa.

\begin{tabular}{|c|c|c|c|c|c|c|}
\hline \multirow[t]{2}{*}{ Animal } & \multirow[t]{2}{*}{ Parity } & \multirow[t]{2}{*}{ Oestrus } & \multicolumn{2}{|c|}{ Interval } & \multicolumn{2}{|c|}{ No. of spermatozoa } \\
\hline & & & $\begin{array}{c}\text { injection- } \\
\text { insemination }\end{array}$ & $\begin{array}{l}\text { insemination- } \\
\text { slaughter }\end{array}$ & inseminated & recovered \\
\hline C & 0 & spontaneous & - & $2 \mathrm{~h}$ & $200 \times 10^{6}$ & 17850 \\
\hline B & 0 & , & - & $2 \mathrm{~h}$ & $200 \times 10^{6}$ & 3429 \\
\hline $\mathbf{F}$ & 1 & induced & $72 \mathrm{~h}$ & $2 \mathrm{~h}$ & $200 \times 10^{6}$ & 294 \\
\hline $\mathbf{A}$ & 0 & spontaneous & - & $12 \mathrm{~h}$ & $200 \times 10^{6}$ & 69 \\
\hline G & 1 & induced & $84 \mathrm{~h}$ & $12 \mathrm{~h}$ & $20 \times 10^{6}$ & 36 \\
\hline $\mathbf{E}$ & 1 & , & $72 \mathrm{~h}$ & $2 \mathrm{~h}$ & $20 \times 10^{6}$ & 9 \\
\hline H & 1 & " & $84 \mathrm{~h}$ & $12 \mathrm{~h}$ & $200 \times 10^{6}$ & 3 \\
\hline D & 1 & spontaneous & - & $2 \mathrm{~h}$ & $20 \times 10^{6}$ & 1 \\
\hline
\end{tabular}

Four animals were inseminated in cloprostenol $(0.5 \mathrm{mg}$ Estrumat, Leo, Sweden) induced oestrus at 72 or $84 \mathrm{~h}$ after injection. Two of these animals, $E$ and $F$, were in standing oestrus at insemination. The remaining 4 animals were inseminated late in spontaneous oestrus when they allowed mounting attempts by a bull (Table 1). By use of an ordinary insemination gun (IMV, L'Aigle, France) the semen was deposited in the body of the uterus.

\section{Recovery of spermatozoa}

The animals were slaughtered 2 or $12 \mathrm{~h}$ after insemination (Table 1). After stunning and bleeding the genital tract was removed. Clamps were placed at the tip of the uterine horn and at the infundibulum. The oviducts were straightened by trimming 
off the connective tissue and then mounted on cork plates with pins. After fixation in Bouine-Holland's fixative for 3 days the oviducts were cut into segments. All segments were approximately $3 \mathrm{~cm}$ long except the uterotubal junction (UTJ) which comprised $1.5 \mathrm{~cm}$ of the tip of the uterine horn and $1 \mathrm{~cm}$ of the distal oviduct. The segments were longitudinally sectioned to a thickness of $4 \mu$. Every 10th section was mounted and stained with haematoxyline and eosin. The 6 middle sections mounted from each segment were chosen and studied under the light microscope $(312 \times)$. In 1 animal $(F)$ all sections were examined. The number and location of recovered spermatozoa, both intact spermatozoa and detached heads, were recorded. The junction between isthmus and ampulla( AIJ) was in each oviduct defined as the part of the oviduct where the muscular layer gets thinner and the mucosal folds increase in size.

\section{RESULTS}

The method applied for sperm recovery in the present study gave accurate information concerning sperm localization within the oviducts. However, the examination and evaluation of the sections was very time consuming and therefore the number of examined sections was limited to 6 from each segment. The comparison between examination of all sections mounted vs. examination of the 6 middle sections from each segment revealed good agreement between the two ways of examination (Fig. 1). Deviations were, however, seen if spermatozoa appeared in large
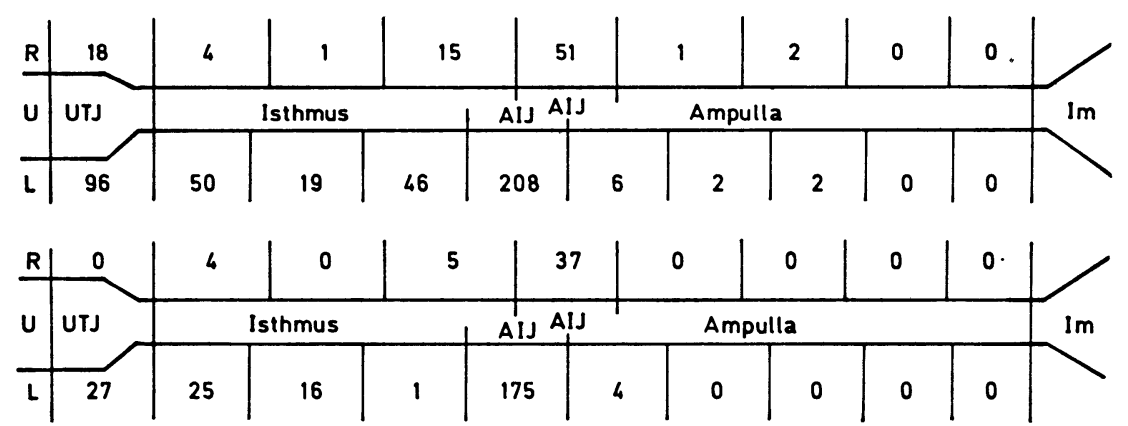

Figure 1. Recovery of spermatozoa in the left (L) and right (R) oviduct of one animal when all mounted sections were counted (upper figure) and when the 6 middle sections were counted (lower figure). $\mathrm{U}=$ uterus, $\mathrm{UTJ}=$ uterotubal junction, AIJ $=$ ampullaryisthmic junction, $\operatorname{Im}=$ infundibulum. 
conglomerates or when the number of sections per segment was large.

The total recovery of spermatozoa in each animal, based on examination of 6 sections from each segment, is presented in Table 1. There was a large variation among the individual animals. When $20 \times 10^{6}$ spermatozoa were inseminated the sperm recovery was low. In the 2 cows that were inseminated in induced oestrus with $200 \times 10^{6}$ spermatozoa recovery was extremely low in one and higher in the other.

The relative distribution of spermatozoa in the oviducts of the 4 animals in which more than 50 spermatozoa were found is shown in Fig. 2 and summarized in Table 2. The number of spermatozoa recovered from the different segments varied

A

\begin{tabular}{l|l|l|l|l|l|l|l|l|l|l|l|l}
$R$ & 24.6 & 15.9 & 2.9 & 1.5 & 0 & 0 & 0 & 0 & 0 & 0 & 0 & \\
\hline$U$ & UTJ & Isthmus & AIJ & \multicolumn{7}{|c|}{ Ampulla } \\
\hline$L$ & 15.9 & 4.4 & 11.6 & 10.1 & 7.3 & 4.4 & 1.4 & 0 & 0 & 0 & 0 & $*$
\end{tabular}

B

\begin{tabular}{c|c|c|c|c|c|c|c|c|c|c|c}
$R$ & 30.1 & 6.6 & 1.0 & 0.1 & 13.5 & 0 & 0 & 0 & 0 & \\
\hline$U$ & $U T J$ & \multicolumn{2}{|c|}{ Isthmus } & AIJ & \multicolumn{3}{|c|}{ Ampulla } \\
\hline$L$ & 0.7 & 0.2 & 47.8 & 0 & 0 & 0 & 0 & 0 & 0 & Im
\end{tabular}

C

\begin{tabular}{c|c|c|c|c|c|c|c|c|c|c|c|c}
$\mathrm{R}$ & 0.2 & 0.9 & 3.6 & 2.3 & 3.3 & 10.8 & 5.4 & 3.5 & 0.2 & 0.1 & 0.4 & $*$ \\
\hline U & UTJ & \multicolumn{6}{|c|}{ Isthmus } & AIJ & \multicolumn{3}{|c|}{ Ampulla } \\
\hline L & 0.1 & 0.8 & 2.4 & 0.2 & 50.4 & 6.5 & 8.2 & 0.4 & 0.1 & 0.2 & 0 & Im
\end{tabular}

$F$\begin{tabular}{c|c|c|c|c|c|c|c|c|c|c|c}
$R$ & 0 & 1.4 & 0 & 1.7 & 12.6 & 0 & 0 & 0 & 0 & $*$ \\
\hline$U$ & UTJ & \multicolumn{7}{|c|}{ Isthmus } & \multicolumn{1}{|c|}{ AIJ AIJ Ampulla } \\
\hline$L$ & 9.2 & 8.5 & 5.4 & 0.3 & 59.5 & 1.4 & 0 & 0 & 0 & 0 & Am
\end{tabular}

Figure 2. Relative distribution of spermatozoa within the right (R) and left ( $L$ ) oviduct in 4 animals (A, B, C and F).

$\mathrm{U}=$ uterus, $\mathrm{UTJ}=$ uterotubal junction, $\mathrm{AIJ}=$ ampullaryisthmic junction, $\mathrm{Im}=$ infundibulum.

* indicates the side with the follicle bearing ovary. 
T a b l e 2. Relative sperm distribution in the oviducts (left and right added) and mean rank order (RO) in the 4 animals from which more than 50 spermatozoa were recovered.

\begin{tabular}{lcrrrr}
\hline Segment & \multicolumn{5}{c}{ Animals } \\
\cline { 2 - 6 } & A & \multicolumn{1}{c}{ B } & \multicolumn{1}{c}{ C } & \multicolumn{1}{c}{ F } & Mean RO \\
\hline UTJ & 40.5 & 30.8 & 0.3 & 9.2 & 2.5 \\
Isthmus & 34.8 & 55.6 & 63.9 & 17.3 & 1.5 \\
AIJ & 11.6 & 0.1 & 17.3 & 72.1 & 3.0 \\
Ampulla & 13.1 & 13.5 & 18.5 & 1.4 & 3.0 \\
\hline
\end{tabular}

considerably among animals and also between the left and the right oviduct in the same animal. In 3 animals more spermatozoa were recovered from the left oviduct (A: $55.1 \%, \mathrm{C}: 69.3 \%, \mathrm{~F}$ : $84.3 \%$ ), while in animal $B$ the distribution in the 2 oviducts was almost the same (51.3 vs. $48.7 \%$ ). Only in 1 animal (A) were the majority of spermatozoa recovered from the oviduct ipsilateral to the follicle-bearing ovary.

If the number of spermatozoa recovered from the left and the right oviducts in animals $\mathrm{A}, \mathrm{B}, \mathrm{C}$ and $\mathrm{F}$ are added together the majority of spermatozoa were recovered from the UTJ in animal $A$, from the isthmus in animals $B$ and $C$ and from the
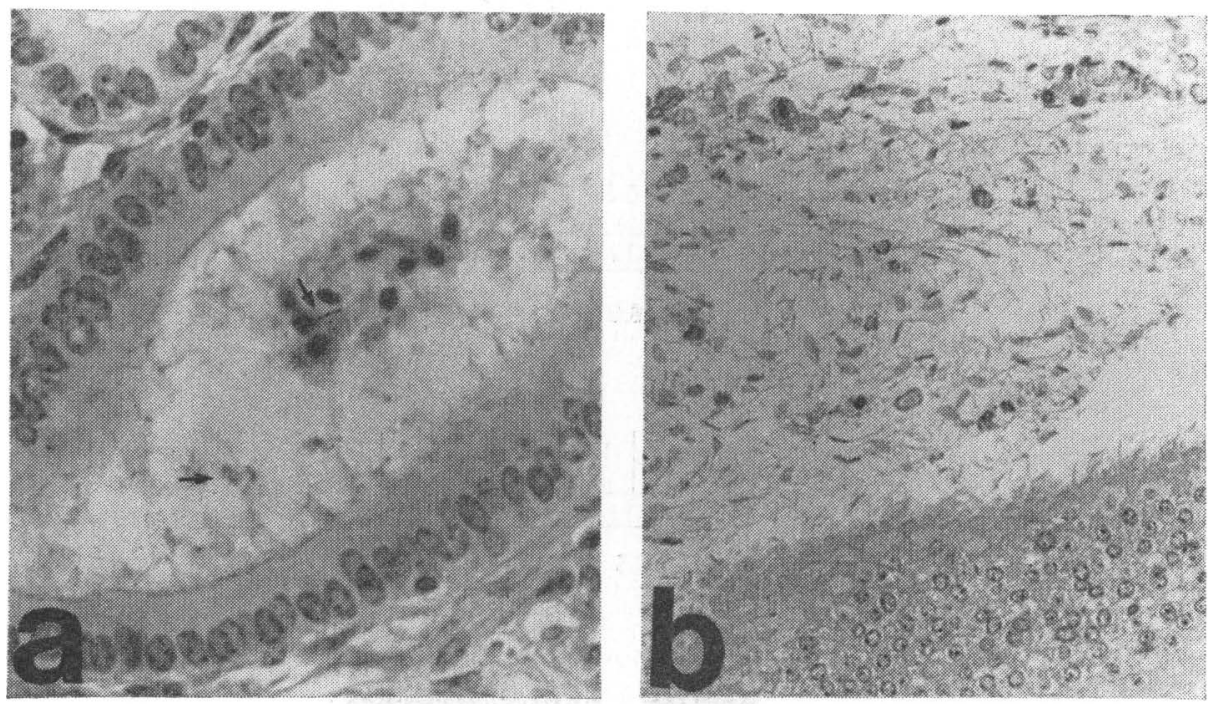

Figure 3. a Single spermatozoa (arrows) in the uterotubal junction $(x 400)$. b: Conglomerate of spermatozoa in the isthmic lumen $(x 400)$. 
AIJ in animal F. In all animals only a minor part of the spermatozoa were recovered from the ampulla.

The spermatozoa were either recovered as single cells or in conglomerates. The conglomerates comprised from 10 up to hundreds of spermatozoa, often together with epithelial cells. They were mostly found in the isthmus and AIJ. In the UTJ spermatozoa were localized in the central lumen as well as in the deep crypts.

\section{DISCUSSION}

The present study was undertaken to investigate the localization of spermatozoa within the oviducts after AI with frozen semen. Certain methodological aspects were also involved in the experiments.

The segmental distribution of spermatozoa was evaluated only in animals from which at least 50 spermatozoa had been recovered. Although there was a considerable variation among and within animals, the results indicate that the lower parts of the oviducts contain more spermatozoa than the upper parts. Thibault (1973) found an abrupt decrease in sperm numbers a few centimetres before the ampulla. Histologically there is a gradual change from isthmus to ampulla. This seems, however, to coincide with decreasing sperm numbers within the organ. This may have two explanations: either the spermatozoa are "trapped" in the lower part of the oviduct or are they transported rapidly through the upper part of the oviduct. In either case the result is likely to be the same, i.e. low sperm number in the upper part of the oviduct.

The disproportion of spermatozoa between the left and the right oviduct found in this study is in agreement with results obtained after flushing of bovine oviducts (Larsson \& Larsson 1985). Furthermore, the presence of a preovulatory follicle in an ovary did not seem to result in a higher number of spermatozoa in the ipsilateral oviduct. This is also in accordance with previous experiments (Larsson \& Larsson 1985, Larsson 1986).

The number of spermatozoa inseminated largely influenced sperm recovery in the oviducts. In none of the animals inseminated with $20 \times 10^{6}$ spermatozoa, which is the standard sperm number used for AI in Sweden, was the sperm recovery high enough for evaluation. The reason for this is most likely 
that only a minor portion of the spermatozoa inseminated will reach the oviducts, while the major part is lost by backflow through the cervix into the vagina (Larsson \& Larsson 1985, Mitchell et al. 1985). It is less likely that the sperm number as such influences the mechanism of sperm transport. Therefore high sperm numbers must be used in studies on sperm transport and distribution.

The method used for sperm recovery was very time consuming. The reduction of the number of sections examined from each segment decreased sperm recovery by a little less than $50 \%$. However, the fact that so many spermatozoa were found in large conglomerates will imply an underestimation of the number of spermatozoa if conglomerates remain undetected in unexamined sections. After flushing of the oviducts it is more likely that all of these conglomerates will be recovered. A question that deserves further experimental effort is the functional meaning of these sperm conglomerates.

The effect of oestrus induction on sperm transport can certainly not be evaluated from the present study. However, the use of fixed-time AI, which is of great help in experiments including planned slaughter of large animals, was not very successful since 2 animals showed oestrus before AI. Sperm recovery was in these cases very poor. The only case in which fixed-time AI yielded acceptable sperm recovery was an animal that showed external signs of heat at the time of $\mathrm{AI}$ and that was inseminated with $200 \times 10^{6}$ spermatozoa.

\section{CONCLUSIONS}

The information obtained by serial sectioning of the oviducts was similar to and in agreement with what has been found after flushing of the oviducts. Considering the amount of work involved and the accuracy in quantitation of sperm recovery, flushing of the oviducts combined with histological examination of control sections seems to be the method of choice for evaluation of sperm transport and distribution.

High sperm numbers must be used to enable quantitation of the sperm number that is actually transported into the oviducts. The usefulness of fixed time $A I$ is doubtful in sperm transport studies. 


\section{ACKNOWLEDGEMENT}

This work was supported by grants from the Swedish Council for Forestry and Agricultural Research. The authors are indebted to Miss Britt Jönsson and Miss Catharina Falkenberg for technical assistance.

\section{REFERENCES}

Dobrowolski, W. \& E. S. E. Hafez: Transport and distribution of spermatozoa in the reproductive tract of the cow. J. Anim. Sci. 1970, 31, 940-943.

El Banna, A. A. \& E. S. E. Hafez: Sperm transport and distribution in rabbit and cattle female tract. Fertil. Steril. 1970, 21, 534-540.

Larsson, B.: Sperm distribution in artificially inseminated heifers. A preliminary report. Proc. 10th Int. Congr. on Anim. Repr. and AI, Urbana-Champaign 1984, Vol. III, pp. 372-374.

Larsson, B.: Transuterine transport of spermatozoa after artificial insemination in heifers. Anim. Repr. Sci. 1986, 12, 115-122.

Larsson, B. \& K. Larsson: Distribution of spermatozoa in the genital tract of artificially inseminated heifers. Acta vet. scand. 1985, $26,385-395$.

Mitchell, J. R., P. L. Senger \& J. L. Rosenberger: Distribution and retention of spermatozoa with acrosomal and nuclear abnormalities in the cow genital tract. J. Anim. Sci. 1985, 61, 956-967.

Thibault, C.: Sperm transport and storage in vertebrates. J. Reprod. Fert. 1973, Suppl. 18, 39-53.

Thibault, C., M. Gerard \& Y. Heyman: Transport et survie des spermatozoides chez la vache. (Transport and survival of spermatozoa in cattle). Proc. INSERM, 4-7 Nov. 1973, Vol. 26, pp. 343-356.

\section{SAMMANFATTNING}

Lokalisation av spermier $i$ äggledarna hos nötkreatur efter artificiell insemination.

Åtta djur, 3 kvigor och 5 förstakalvare, inseminerade med tjursperma fryst i mini-payetter. Varje dos innehöll $20 \times 10^{6}$ eller $200 \times 10^{6}$ spermier, som deponerades i corpus uteri. Fyra djur inseminerades $i$ spontan brunst medan de övriga 4 inseminerades på bestämda tidsintervall (72 eller 84 timmar) efter cloprostenol injektion (Estrumat, Leo). Två eller 12 timmar efter inseminationen slaktades djuren. Äggledarna fixerades och indelades i segment. Segmenten seriesnittades och färgades. Sex snitt per segment undersöktes i mikroskop avseende förekomst och lokalisation av spermier.

Antalet spermier, som återfanns $i$ äggledarna, varierade mellan de olika djuren. Hos 4 djur var antalet återfunna spermier lågt (färre än 50). Få spermier återfanns när inseminationen skedde $i$ inducerad brunst och med det lägre spermieantalet $\left(20 \times 10^{6}\right)$. Hos de djur, där fler än 50 spermier återfanns, varierade fördelningen av spermier 
både mellan djur och mellan äggledare från samma djur. Sammanfattningsvis återfanns flera spermier i de nedre delarna (UTJ, isthmus och AIJ) av äggledarna jämfört med de övre (ampulla). Hos 3 av 4 djur fanns fler spermier på vänster än på höger sida. Bara ett djur hade merparten av spermierna på den sidan där äggstocken med den preovulatoriska follikeln fanns.

(Received March 20, 1986).

Reprints may be requested from: Birgitta Larsson, the Department of Obstetrics and Gynaecology, Swedish University of Agricultural Sciences, S-750 07 Uppsala, Sweden. 